\title{
Case study THE CLINICAL APPLICATION OF IMPLEMENTED INTERNATIONAL CLASSIFICATION OF FUNCTIONING, DISABILITY AND HEALTH (ICF) MODEL FOR REHABILITATION TREATMENT IN SUBACROMIAL IMPINGEMENT SYNDROME
}

\author{
ZASTOSOWANIE KLINICZNE MODELU MIĘDZYNARODOWEJ KLASYFIKACJI \\ FUNKCJONOWANIA, NIEPEENOSPRAWNOŚCI I ZDROWIA (ICF) W LECZENIU \\ REHABILITACYJNYM ZESPOEU CIASNOTY PODBARKOWEJ
}

\section{Ewa Chlebuś, Przemysław Lisiński}

Clinic for Rehabilitation, Poznań University of Medical Sciences, Poznań, Poland

\section{ABSTRACT}

\section{Introduction}

The ICF classification describes, based on categories, functioning at the body level (disability), people (activities) and people in society (participation) taking into account the environmental factors. ICF tools were developed based on ICF Core Set for the management of the rehabilitation process.

\section{Aim}

This publication, based on a case study, presents a proposal for a set of categories for functional assessment of the upper limb for patients with subacromial impingement syndrome and a proposal for intervention by individual members of the rehabilitation team.

\section{Material and methods}

We present a retrospective study (analysis of medical records) of a 55-year-old woman hospitalized in the Out Patient Ward of the Rehabilitation Clinic because of left shoulder pain not caused by injury. The rehabilitation tretament provided to this patient included 5 patient management components : examination, evaluation, prognosis, diagnosis, and intervention using the ICF-based documentation tool.

\section{Results}

After rehabilitation, resting pain in the shoulder girdle (from VAS 8 to VAS 3) decreased, muscle strength increased ( from 4 to 5 on the Lovett scale) and range of movement without pain, no changes in shoulder imaging results were noted. The patient regained partial independence in self-service activities. She still had trouble performing her upper limb elevation.

\section{Conclusions}

The ICF classification enables effective global and specific goals of the rehabilitation program, as well as facilitates planning the intervention of individual members of the rehabilitation team. The presented case report was the first clinical study on the use of ICF in the shouldertight syndrome.

Keywords: ICF, shoulder rehabilitation, subacromial impingement syndrome 


\section{STRESZCZENIE}

\section{Wstęp}

Klasyfikacja ICF (ang. International Classification of Functioning, Disability and Health) opisuje na podstawie kategorii funkcjonowanie na poziomie ciała (upośledzenia), osoby (czynności) oraz osoby w społeczeństwie (uczestnictwo) przy uwzględnieniu czynników środowiskowych. Do zaplanowania programu rehabilitacji wykorzystano narzędzia ICF opracowane w oparciu o zestaw podstawowy ICF.

\section{Cel}

Niniejsza publikacja, na podstawie studium przypadku przedstawia propozycję zestawu kategorii oceny funkcjonalnej kończyny górnej dla chorych z zespołem ciasnoty podbarkowej oraz propozycję interwencji przez poszczególnych członków zespołu rehabilitacyjnego.

\section{Materiał i metody}

Badanie retrospektywne na podstawie analizy dokumentacji medycznej 55-letniej pacjentki hospitalizowanej w Oddziale Dziennego Pobytu Kliniki Rehabilitacji z powodu dolegliwości bólowych barku lewego, które wystąpiły nagle bez urazu. Dokumentacja medyczna leczenia rehabilitacyjnego u tej pacjentki obejmowała 5 elementów: badanie, ocenę funkcjonalną, rokowanie, diagnozę i interwencję przy zastosowaniu klasyfikacji ICF.

\section{Wyniki}

Po leczeniu rehabilitacyjnym zmniejszyły się dolegliwości bólowe obręczy barkowej z 8 na 3 według skali VAS, zwiększyła siła mięśniowa z 4 na 5 według skali Lovett i zakres ruchu bez dolegliwości bólowych, nie odnotowano zmian w wynikach obrazowych obręczy barkowej. Pacjentka odzyskała częściową niezależność w czynnościach samoobsługowych. Nadal ma problemy z wykonywaniem czynności z uniesieniem kończyny górnej.

\section{Wnioski}

Klasyfikacja ICF umożliwia skutecznie wyznaczyć cele globalne i szczegółowe programu rehabilitacyjnego, jak również zaplanować interwencje poszczególnych członków zespołu rehabilitacyjnego. Przedstawiony opis przypadku jest pierwszym badaniem klinicznym $\mathrm{z}$ zastosowaniem klasyfikacji ICF w zespole ciasnoty podbarkowej.

Słowa kluczowe: ICF, rehabilitacja barku, zespół ciasnoty podbarkowej

\section{Introduction}

On June 18, 2018, the World Health Organization (WHO) issued a version of the ICD-11 (International Statistical Classification of Diseases and Related Health Problems). which was presented at the 72nd World Health Assembly - May 25, 2019. All Member States are to report using this classification from 1 January 2022 (Editorial Lancet 2018). The ICD 11 classification currently consists of the commonly used ICD 10 health and disease assessment classification and the implemented International Classification of Functioning, Disability and Health (ICF) classification (Nishio et al. 2019). The ICF classification supplements the ICD-10 classification (Stucki et al., 2017). The ICD-10 classification describes diseases, injuries, disorders and related health problems (Escorpizo et al. 2013). The ICF classification describes, based on categories, functioning at the body level (disability), 
people (activities) and people in society (participation) taking into account environmental factors. (Selb et al. 2015). To determine the scale of the problem in ICF categories, ICF qualifiers are used, which are based on numerical scales from 0 to 4 (0: no problem (0\%-4\%): 1 : mild problem (5\%-24\%); 2: moderate problem (25\%-49\%); 3: serious problem (50\%-95\%); 4: full problem (96\%-100\%). Environmental factors are quantified using a negative and positive scale indicating the extent to which the environmental factor acts as a barrier or facilitator (0: none 1:mild; 2: moderate 3: strong; 4: total barrier) (Rauh et al. 2010). ICF-based documentation tools have been developed for use at various stages of rehabilitation (socalled rehabilitation cycle) with a proposal of the direction and scope of intervention of individual members of the rehabilitation team. The documentation tools consist of the ICF categorical profile, the ICF initial assessment sheet, the ICF intervention table and the ICF evaluation sheet (Rauch et al., 2008). Each of these tools can be used at various stages of the rehabilitation process.

To facilitate the use of ICF in widespread clinical practice, the WHO team developed various ICF base sets and shortened ICF (core sets) for specific disease entities (Yen et al., 2014). On the website https://www.icf-core-sets.org/en/ pagel.php WHO proposes ICF category sets for patients with musculoskeletal injuries (Musculoskeletal ICF core sets), for patients treated with rehabilitation (rehabilitation set). However, there is no published set for assessing upper limb dysfunction depending on the cause of the disease. Previous scales modeled on the ICF classification (e.g. DASH) based on the self-assessment of the functional activity of the upper limb do not globally assess damage to the function and structure of the upper limb, which has a direct impact on the activity and participation in social life of the patient with upper limb dysfunction.

\section{Aim}

This publication, based on a case study, presents a proposal for a set of categories for functional assessment of the upper limb for patients with subacromial impingement syndrome and a proposal for intervention by individual members of the rehabilitation team.

\section{Material and methods}

Case report

We present a retrospective study (analysis of medical records) of a 55-year-old woman hospitalized in the Out Patient Ward of the Rehabilitation Clinic because of left shoulder pain not caused by injury. During the initial examination, she reported pain located in the front of the shoulder and in the upper-lateral part of the arm, preventing lying on the affected side. The described pain awakened the patient at night. In addition, the patient reported parasthesia located in the upper arm, weakness of the muscular strength of the limb and severe pain when performing activities with lifting the limb, such as hanging curtains or cleaning windows. During the treatment she was on sick leave due to the described pain. She is an accountant by profession, working on average 7 hours a day on a computer station. Before shoulder pain occurred, she participated in various physical activities such as swimming in the pool or cycling. He also has chronic hypertension. The patient had a limited range of active adduction and flexion movement, which after exceeding 90 degrees was accompanied by severe pain assessed by her on 8 on the VAS scale. In addition, weakness in shoulder girdle muscle strength (4 according to the Lovett scale) and an abnormal posture in the form of head and shoulder protraction was found, which resulted in increased kyphosis in the upper thoracic spine.

X-ray examination showed narrowing of the subacromial space in the course of advanced osteophytosis. The ultrasound examination described features of chronic bursitis (edema and fluid) and edema of the supraspinate muscle tendon and long head biceps tendon. The patient gave her written consent to participate in this study. The current report was created after the end of the 4-week cycle of rehabilitation treatment. 


\section{Examination}

For the initial assessment in this case study, a set of basic ICF categories was used, presented in the publications of Roe et al. 2013 to assess shoulder pain. The results of the medical examination were recoded into ICF categories. Figure 1 shows the ICF categorical profile. The results of the basic categories of the ICF set showed various limitations in upper limb dysfunction and dependence on the environment.

\section{Diagnosis}

The ICF assessment sheet (see Figure 2) containing a comprehensive definition of the patient's functional dysfunctions and consists of 2 parts: The upper part indicates the complications that the patient experiences and is supplemented by a routine interview with the patient. The bottom of the sheet reflects a clinical examination by a physician. A relationship can be found between the patient's complications and the factors that caused the functional dysfunction including the patient's motor complications (upper part of the sheet).

\section{Plan of treatment}

The goals of the rehabilitation program were determined by patient participation and consideration of the various components of ICF. The main goal of the patient (PG) was to regain independence. The patient's long-term goal (LTG) was to regain the ability to drive and return to full efficiency at work. Two short-term goals (STGs) have been identified. First, improving the range of motion of the upper limb, second, improving the patient's ability to achieve maximum independence in daily activities (ADL), such as toilet and dressing. The goals were entered into the ICF categorical profile and ICF evaluation sheet. Intervention goals were selected in accordance with the goals set by talking to the patient. The goal value was set for each of the first and second short-term goals to be achieved by the end of the rehabilitation cycle.

\section{Intervention}

The sample documentation template in Table 1 shows some interventions of rehabilitation team members. A set of interventions is provided for each ICF category. In line with the short-term goals set, various interventions were used to improve traffic range and ADL. During the rehabilitation cycle, the patient had a rehabilitation program planned, including physiotherapeutic exercises and techniques to improve deep sensation, range of motion, tissue elasticity, and muscular strength and endurance within the shoulder joint.

\section{Results}

The patient's functional status was re-assessed at the end of the 4-week rehabilitation cycle and the results are presented in Figure 3. After rehabilitation, resting pain in the shoulder girdle (VAS 3) decreased, muscle strength increased (5 on the Lovett scale) and range of movement without pain. Despite the fact that the structure was disturbed, the patient regained partial independence in self-service activities such as preparing meals, using the toilet, getting dressed. She still had trouble performing her upper limb elevation.

\section{Discussion}

Philbois et al. In 2016, by examining healthcare professionals, they proved that elements of commonly used scales in the assessment of the upper limb can be associated with elements of ICF classification. Also van de Ven-Stevens et al. 2015 proved that ICF classification is the best tool for organizing data on upper limb dysfunction, however, the authors only undertook the evaluation of hand function. In turn, Vincent et al. 2015 by examining the usefulness of the ICF category in elbow joint assessment, they proved that the ICF assessment sheet can perfectly reflect useful data on the functional conditions of patients. In the available literature only Roe et al.2013 undertook to assess the shoulder according to the ICF classification. These researchers focused only on the activity and participation of the patient with shoulder 
Ewa Chlebuś, Przemysław Lisiński: The clinical application of implemented international classification of functioning...

\begin{tabular}{|c|c|c|c|c|c|c|c|c|c|c|}
\hline \multicolumn{11}{|l|}{ ICF Categorical Profile - subacromial impingement syndrome } \\
\hline \multicolumn{11}{|l|}{ Assessment } \\
\hline Patient Goal: Optimal independence in daily living & & & & & & & & & & 3 \\
\hline $\begin{array}{l}\text { Long term goal (LTG): Health maintenance and community } \\
\text { reintegration }\end{array}$ & & & & & & & & & & 2 \\
\hline Short term goal (STG1): Improved use of hands and arms & & & & & & & & & & 1 \\
\hline Short term goal (STG2): Increased independence in self-care & & & & & & & & & & 0 \\
\hline \multirow{3}{*}{ ICF categories } & \multicolumn{8}{|c|}{ ICF Qualifier } & $\begin{array}{l}\text { Goal } \\
\text { relation }\end{array}$ & $\begin{array}{l}\text { Goal } \\
\text { value }\end{array}$ \\
\hline & & & & \multicolumn{5}{|c|}{ problem } & & \\
\hline & & & & 0 & 1 & 2 & 3 & 4 & & \\
\hline \multicolumn{11}{|l|}{ BODY FUNCTIONS } \\
\hline b134 Sleep functions & & & & & & & & & LTG & 2 \\
\hline b265 Touch function & & & & & & & & & & 1 \\
\hline b280 Sensation of pain & & & & & & & & & SGTl & 2 \\
\hline b710 Mobility of joint functions & & & & & & & & & SGT1 & 1 \\
\hline b715 Stability of joint functions & & & & & & & & & SGTl & 1 \\
\hline b720 Mobility of bone functions & & & & & & & & & SGT1 & 1 \\
\hline b730 Muscle power functions & & & & & & & & & SGT1 & 1 \\
\hline \multicolumn{11}{|l|}{ b735 Muscle tone functions } \\
\hline b740 Muscle endurance functions & & & & & & & & & SGTl & 1 \\
\hline $\begin{array}{l}\text { b780 Sensations related to muscles and movement } \\
\text { functions }\end{array}$ & & & & & & & & & SGT1 & 1 \\
\hline b840 Sensation related to the skin & & & & & & & & & SGTl & \\
\hline \multicolumn{11}{|l|}{ BODY STRUCTURES } \\
\hline \multicolumn{11}{|l|}{ s710 Structure of head and neck region } \\
\hline s720 Structure of shoulder region & & & & & & & & & SGT1 & 1 \\
\hline \multicolumn{11}{|l|}{ s730 Structure of upper extremity } \\
\hline \multicolumn{11}{|l|}{ ACTICITIES \& PARTICIPATION } \\
\hline \multicolumn{11}{|l|}{ dl70 Writing } \\
\hline \multicolumn{11}{|l|}{ d415 Maintaining a body position } \\
\hline d430 Lifting and carrying objects & & & & & & & & & SGTl & 3 \\
\hline \multicolumn{11}{|l|}{ d440 Fine hand use } \\
\hline d445 Hand and arm use & & & & & & & & & SGTl & 3 \\
\hline d475 Driving & & & & & & & & & SGT1 & 1 \\
\hline d510 Washing oneself & & & & & & & & & SGTl & 1 \\
\hline d530 Toileting & & & & & & & & & SGT1 & 1 \\
\hline d540 Dressing & & & & & & & & & SGTl & 1 \\
\hline \multicolumn{11}{|l|}{ d550 Eating } \\
\hline d630 Preparing meals & & & & & & & & & SGT1 & 1 \\
\hline d640 Doing housework & & & & & & & & & STG2 & 3 \\
\hline d850 Remunerative employment & & & & & & & & & STG2 & 3 \\
\hline d920 Recreation and leisure & & & & & & & & & STG2 & 3 \\
\hline \multirow{2}{*}{ ENVIRONMENTAL FACTORS } & \multicolumn{3}{|c|}{ facilitator } & & \multicolumn{4}{|c|}{ barrier } & & \\
\hline & \begin{tabular}{l|l}
$4+$ & $3+$
\end{tabular} & $2+$ & $1+$ & 0 & 1 & 2 & 3 & 4 & & \\
\hline el101 Drugs & & & & & & & & & 1 & $2+$ \\
\hline \multicolumn{11}{|l|}{$\begin{array}{l}\text { el20 Products and technology for personal indoor and } \\
\text { outdoor mobility and transportation }\end{array}$} \\
\hline \multirow{2}{*}{ PERSONAL FACTORE (PF) } & Influence & & & & & & & & & \\
\hline & Positive & & $\mathrm{Neu}$ & & & & ative & & & \\
\hline Motivation & & & & & & & & & & \\
\hline Attitude toward intervention & & & & & & & & & & \\
\hline
\end{tabular}

Figure 1. ICF Categorical profile 
Ewa Chlebuś, Przemysław Lisiński: The clinical application of implemented international classification of functioning...

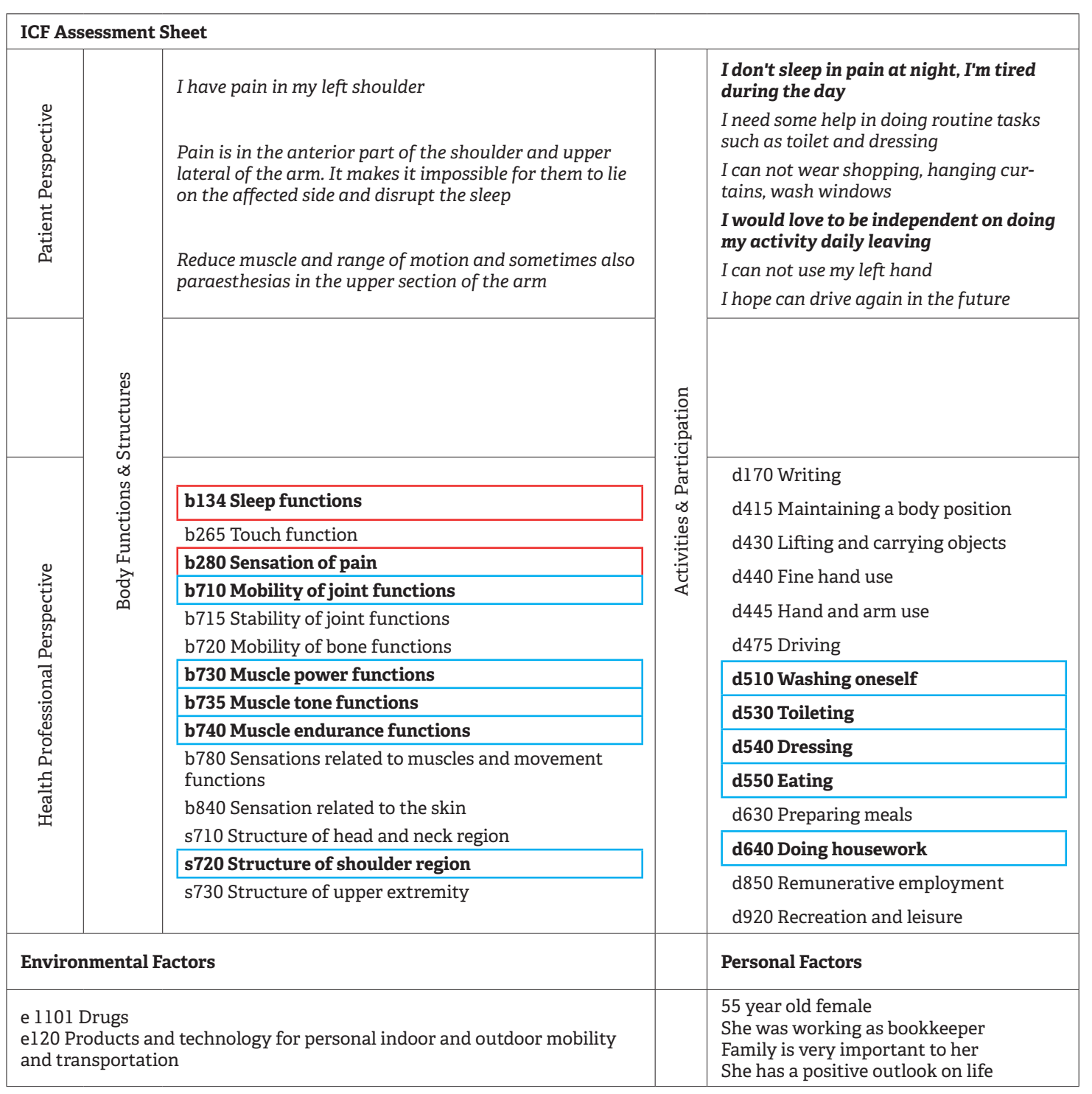

Figure 2. ICF assesment sheet.

pain. In addition, they correlated the results of commonly used DASH and Quick DASH scales with ICF qualifiers. Examining stroke patients Faria-Fortin et al. 2011 proved that the use of the ICF-core in clinical settings allows members of the rehabilitation team to evaluate and monitor the effectiveness of rehabilitation treatment in all functional aspects of the patient. In the ICF evaluation sheet presented in this work (see Figure 3) one can observe the progress of the functional state and assess the effectiveness of rehabilitation interventions, in addition, the evaluation evaluation indicates further goals of the rehabilitation procedure. As Rauch et al.2010 in clinical practice, the use of the ICF Category
Profile dedicated to patients with shoulder girdle disorders can help improve the quality of interdisciplinary care, including communication between healthcare professionals and patients and their family members or careers.

\section{Conclusions}

The ICF classification enables effective global and specific goals of the rehabilitation program, as well as facilitates planning the intervention of individual members of the rehabilitation team. The presented case report was the first clinical study on the use of ICF in the shoulder-tight syndrome. However, further research should be carried out to find the best method of implementing ICF in the 
Ewa Chlebuś, Przemysław Lisiński: The clinical application of implemented international classification of functioning...

Table 1. Documentation template

\begin{tabular}{|c|c|c|}
\hline Patient Goal: & \multicolumn{2}{|c|}{ independent living in the community } \\
\hline Long term goal (LTG) & \multicolumn{2}{|c|}{ resumption of work activities } \\
\hline \multicolumn{3}{|l|}{ Short term goal (STG) } \\
\hline STGl & \multicolumn{2}{|c|}{ Improved use of hands and arms } \\
\hline STG2 & \multicolumn{2}{|c|}{ Increased independence in self-care } \\
\hline \multicolumn{3}{|l|}{ Date } \\
\hline \multirow{2}{*}{ ICF Categories } & \multicolumn{2}{|l|}{ Examination } \\
\hline & Test & Intervention \\
\hline \multicolumn{3}{|l|}{ BODY FUNCTIONS } \\
\hline bl34 Sleep functions & Insomnia Severity Index & rehabilitation doctor \\
\hline b280 Sensation of pain & VAS & rehabilitation doctor \\
\hline b710 Mobility of joint functions & ROM shoulder & physiotherapist \\
\hline b730 Muscle power functions & Manual Muscule test & physiotherapist \\
\hline \multicolumn{3}{|l|}{ BODY STRUCTURES } \\
\hline s710 Structure of head and neck region & & rehabilitation doctor \\
\hline s720 Structure of shoulder region & & orthopedic consultation \\
\hline s730 Structure of upper extremity & & rehabilitation doctor \\
\hline \multicolumn{3}{|l|}{ ACTICITIES \& PARTICIPATION } \\
\hline dl70 Writing & Observation & occupational therapist \\
\hline d430 Lifting and carrying objects & Observation & physiotherapist \\
\hline d440 Fine hand use & Observation & occupational therapist \\
\hline d445 Hand and arm use & Observation & physiotherapist \\
\hline d475 Driving & Observation & physiotherapist \\
\hline d510 Washing oneself & ADL & nurse \\
\hline d540 Dressing & ADL & nurse \\
\hline d550 Eating & ADL & nurse \\
\hline d630 Preparing meals & Observation & occupational therapist \\
\hline d640 Doing housework & Observation & occupational therapist \\
\hline d850 Remunerative employment & Observation & career counselor \\
\hline d920 Recreation and leisure & Observation & \\
\hline \multicolumn{3}{|l|}{ ENVIRONMENTAL FACTORS } \\
\hline e 1101 Drugs & Leki & \\
\hline \multicolumn{3}{|c|}{ el20 Products and technology for personal indoor and outdoor mobility and transportation } \\
\hline \multirow[t]{2}{*}{ PERSONAL FACTORE (PF) } & \multicolumn{2}{|l|}{ Influence } \\
\hline & Positive & Negative \\
\hline Motivation & $\mathrm{X}$ & \\
\hline Attitude toward intervention & $\mathrm{X}$ & \\
\hline
\end{tabular}




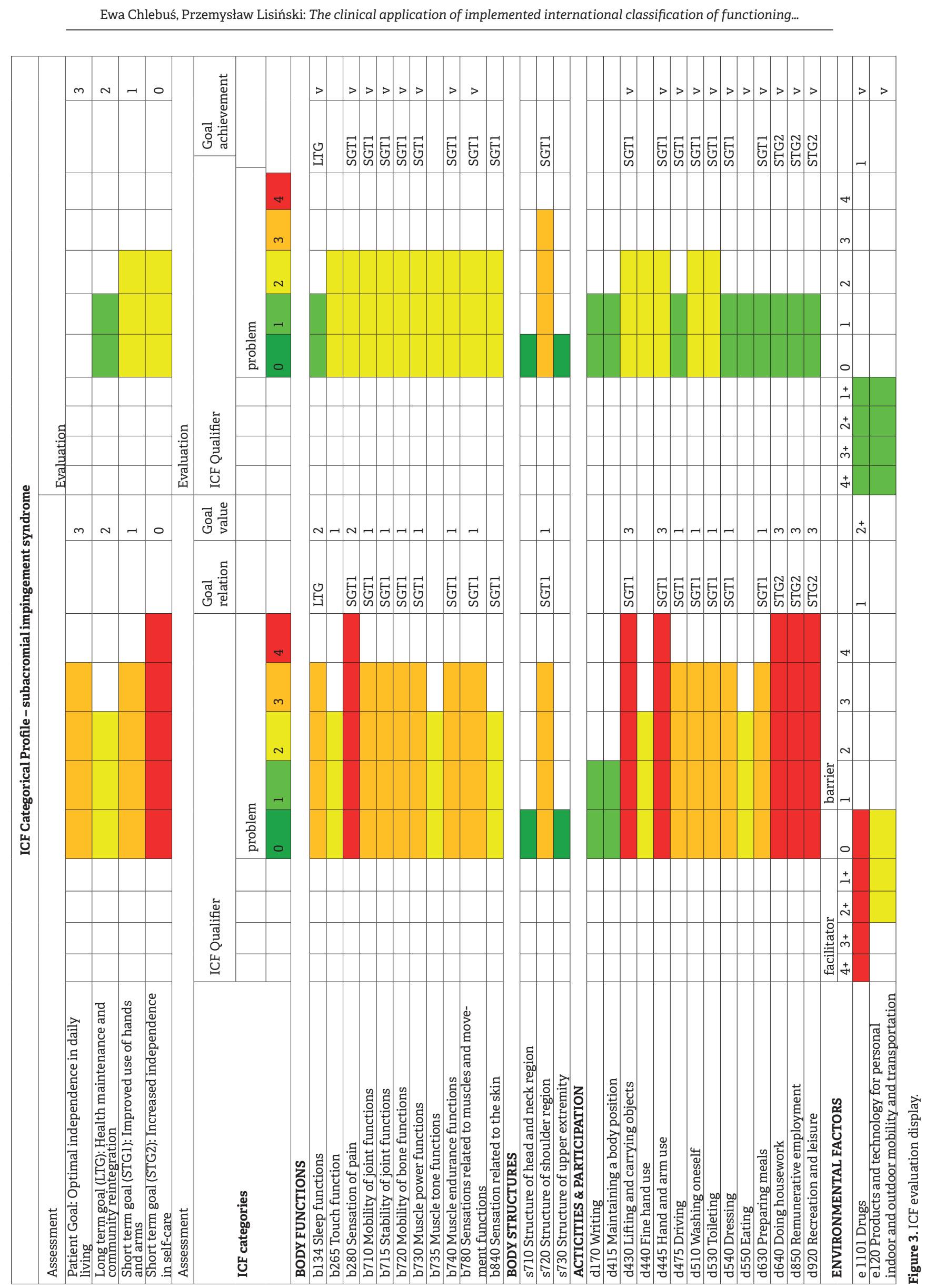


diagnosis and rehabilitation of shoulder girdle disorders. The presented assessment sheet needs to be implemented on a larger group of patients.

\section{REFERENCES}

Editorial (2018) Lancet 391, pp. 2476.

Escorpizo R, Kostanjsek N, Kennedy C, Nicol MM, Stucki G, Ustün TB. (2010) ‘Harmonizing WHO's ICD and ICF: importance and methods to link disease and functioning.' BMC Public Health 13, pp. 742.

Faria-Fortini I, Michaelsen SM, Cassiano JG, Teixeira-Salmela LF. (2011) 'Upper extremity function in stroke subjects: relationships between the international classification of functioning, disability, and health domains.' J Hand Ther. 24, pp.257-264.

Nishio A, Kimura E, Seto R, Sato Y. Mizushima H. (2019) 'The Survey for Determining Knowledge-Related Problems in the Dissemination of ICD-1 1.' Stud Health Technol Inform. 264, pp.1865-1866.

Philbois SV, Martins J, Souza CS, Sampaio RF, Oliveira AS. 'Health professionals identify components of the International Classification of Functioning, Disability and Health (ICF) in questionnaires for the upper limb. Braz J Phys Ther.2016;20:15-25.

Rauch A, Cieza A, Stucki G. (2008) 'How to apply the International Classification of Functioning, Disability and Health (ICF) for rehabilitation management in clinical practice.' Eur J Phys Rehabil Med. 44, pp.329-342. Rauch A, Escorpizo R, Riddle DL, Eriks I, Stucki G, Cieza A. (2010) 'Using a case report of a patient with spinal cord injury to illustrate the application of internatinal classification of functioning, disability and heaith during multidisciplinary patient management.' J Am Phys Ther Assoc. 90; pp.1038-1052.

Roe Y, Bautz-Holter E, Juel NG, Soberg HL. (2013) 'Identification of relevant International Classification of Functioning, Disability and Health categories in patients with shoulder pain: a cross-sectional study.' J Rehabil Med. 45, pp. 662-669.
Roe Y.,Lundegaard Soberg H., Bautz-Holter E. (2013) 'A systematic review of measures of shoulder pain and functioning using the International classification of functioning, disability and health (ICF).' BMC Musculoskeletal Disorders 14, pp. 73.

Selb M, Kohler F, Robinson Nicol MM, Riberto M, Stucki G, Kennedy C, Üstün B. (2015) 'ICD-11: A comprehensive picture of health, an update on the ICD-ICF joint use initiative.' J Rehabil Med.47; pp. 2-8.

Stucki G, Bickenbach J. (2017) 'Functioning: the third health indicator in the health system and the key indicator for rehabilitation.' Eur J Phys Rehabil Med. 53, pp. 134-138.

Yen T, Liou T, Chang K, Wu N, Chou L, Chen H. (2014) 'Systematic review of ICF core set from 2001 to 2012.' Disabil Rehabil. 36, pp.177-184. van de Ven-Stevens LA, Graff MJ, Selles RW, Schreuders TA, van der Linde $H$, Spauwen PH, Geurts AC (2015) 'Instruments for assessment of impairments and activity limitations in patients with hand conditions: A European Delphi study.' J Rehabil Med. 47, pp. 948-956.

Vincent JI, MacDermid JC, King GJ, Grewal R. (2015) 'Linking of the Patient Rated Elbow Evaluation (PREE) and the American Shoulder and Elbow Surgeons - Elbow questionnaire (pASES-e) to the International Classification of Functioning Disability and Health (ICF) and Hand Core Sets.' J Hand Ther. 28, pp. 61-67. 